\title{
Myeloid Progenitor Cell Count
}

National Cancer Institute

\section{Source}

National Cancer Institute. Myeloid Progenitor Cell Count. NCI Thesaurus. Code C130165.

The determination of the number of myeloid progenitor cells in a sample. 